\title{
Veće učešće žena i Izborni zakon BiH
}

\author{
Besima Borić \\ Članica Predsjedništva SDP BiH, \\ političarka i aktivistica \\ besima.boric@gmail.com
}

Sažetak: Vrijeme od 1995. godine do danas obilježeno je, između ostalog, i traganjima za mogućim modelima kako obezbijediti veće učešće žena u zakonodavnim tijelima, ali ne samo u njima, nego i u tijelima izvršne vlasti, ukupnom društvenom i političkom životu. To je proces koji se kontinuirano odvija u velikom dijelu svijeta, pa tako i u našoj $\mathrm{BiH}$, a i u Regiji. Hroničan nedostatak žena na mjestima odlučivanja najčešće se adresira našim tradicionalnim kulturološkim i ukupnim sociološkim uvjetima, nedovoljnoj demokratičnosti političkih subjekata, ali i nedostatku adekvatnih zakonskih rješenja koja bi omogućila dobre uvjete za veći broj žena na listama i u tijelima vlasti. Donošenje Zakona o ravnopravnosti spolova $\mathrm{BiH}$, uvođenje kvote manje zastupljenog spola u Izborni zakon $\mathrm{BiH}$, kao i niz drugih rješenja uveliko je uticalo na povećan broj žena u zakonodavnim tijelima. Još uvijek je taj broj znatno manji od proklamovanog, najprije 30, a potom i 40\% obaveznog broja manje zastupljenog spola na kandidatskim listama. Vrlo je malo istraživanja koja nude moguće konkretne izmjene zakona koje bi dosegle ovaj procent. Opće je mjesto da sadašnji izborni sistem u BiH pogoduje većoj zastupljenosti žena kao manje zastupljenog spola. Ali ,također, otvara i neke mogućnosti za poboljšanje, a koje se kriju u eventualnoj uspostavi pariteta i ravnomjernoj zastupljenosti muškaraca i žena na listama, eventualnom zatvaranju listi, preraspodjeli kompenzacionih mandata $u$ korist manje zastupljenog spola. Također, korisno bi bilo razmotriti i broj političkih subjekata, izbornih jedinica kao i podizanje cenzusa za ostvarenje mandata. Isto tako, važno bi bilo sačuvati kvotu, na koju se u toku dvadesetak godina nekoliko puta atakovalo, ali i zadržati kaznene odredbe kojima se štiti propisani redoslijed i kvota. Izmjene koje bi pogodovale većem broju izabranih žena traže adekvatnu političku klimu i zato je važno adresirati odgovornost ne samo na zakonodavce nego posebno i na političke stranke, medije, NVO i druge subjekte.

Ključne riječi: veća zastupljenost žena, ravnopravnost, ravnomjerna zastupljenost, kvota manje zastupljenog spola, otvorene i zatvorene liste, izmjena kompenzacionih listi, dodjela mandata, povećanje cenzusa, sačuvati pozitivna rješenja, odgovornost političkih subjekata

$* * *$

Ovaj tekst govori o mogućnostima stvaranja i zakonskih, ali i političkih i drugih uvjeta da u BiH bude što veći broj izabranih žena u zakonodavna tijela u $\mathrm{BiH}$, ali i u svim drugim tijelima gdje se donose odluke. 
Zato što je ženama još uvijek potrebna snažna podrška kako bi u javnom životu bile što prisutnije i snažnim djelovanjem doprinijele razvoju države Bosne i Hercegovine.

Kraj 19. i početak 20. vijeka obilježeni su, između ostalog, i ženskom borbom za pravo glasa, za ravnopravnost sa muškarcima, pravo na rad, vrednovanje ženskog rada, mogućnost ravnopravnog uključivanja u donošenje odluka kao i njihovu realizaciju.

Druga polovina dvadesetog vijeka donosi i plodove te borbe, a kraj dvadesetog i godine dvadeset prvog vijeka obilježene su značajnim dostignućima koji se manifestiraju ne samo kroz zakonske pretpostavke za ravnopravno učešće žena u svim sferama života u $\mathrm{BiH}$, nego i u stvaranju različitih institucionalnih mehanizama, političkih pretpostavki i sličnih prilika koje rodnu ravnopravnost i ravnopravno učešće žena i muškaraca u društvenom, političkom i svakom drugom obliku ljudskog djelovanja dižu visoko na ljestvici demokratskih dostignuća u BiH. Svi ovi procesi se odvijaju paralelno i u našoj Regiji, a BiH nimalo ne zaostaje, moglo bi se čak reći i prednjači u njima.

Ustav BiH sadrži i veliki broj međunarodnih konvencija koje su obavezujuće, a koje garantiraju poštivanje ljudskih prava, uz veliki broj zabranjenih osnova diskriminacije. Rodna ravnopravnost nije eksplicite navedena u dejtonskom Ustavu $\mathrm{BiH}$, ali ni na kakav način nije dovedena u pitanje. U sklopu Inicijative Građanke za ustavne promjene (2013), jednim od rodno osjetljivih amandmana, predloženo je da se setu zabranjenih osnova diskriminacije doda i rodni status, a među osnovne vrednote Ustava doda i rodna ravnopravnost.

$\mathrm{BiH}$ se svrstava $\mathrm{u}$ one zemlje koje su prihvatile standarde propisane $\mathrm{i}$ Konvencijom o eliminaciji svih oblika diskriminacije nad ženama (CEDOW), Pekinškom deklaracijom i Platformom za akciju, Agendom UN i ciljevima održivog razvoja 2030 i drugim.

Najznačajnije dostignuće u oblasti ravnopravnosti žena i muškaraca je svakako Zakon o ravnopravnosti spolova $\mathrm{BiH}$, usvojen 2003, nakon velikih aktivnosti žena u NVO i dijela političarki u $\mathrm{BiH}$.

Kada govorimo o izborima i pozicijama žena, važno je napomenuti da su Pekinška deklaracija i Platforma za akciju (1995), po prvi put jasno kvantificirale obavezu vlada potpisnica (189) za učešće žena u svim segmentima djelovanja, najmanje $30 \%$.

Ovo je, zasigurno, bio okidač za aktivnosti koje su uslijedile u narednim godinama u zemljama svijeta, naše Regije i u BiH. Aktivnosti u $\mathrm{BiH}$ su dodatno potaknute poraznim rezultatom broja izabranih žena u Parlamentarnu skupštinu BiH na općim izborima 1996. (2,4\%). 
Tako su 1997. i 1998. godine vođene intenzivne aktivnosti žena u BiH, a koje su iznjedrile kvotu od 30\% manje zastupljenog spola u tzv. Privremenim izbornim pravilima. Ova aktivnost odvijala se pod budnim okom OSCE i njegovog programa „Žena u politici“. Rezultat je bio sjajan: U Zastupnički dom Parlamenta FBIH tad je izabrano i danas nedostižnih 26\% žena. U izborima 1998. smo imali tzv. zatvorene liste. Kasnije će u mnogim raspravama oko zatvorenih i otvorenih listi, ovo dostignuće o broju izabranih žena biti često korišteno kao argument za zatvaranje listi, o čemu će kasnije biti riječi u ovom radu.

U međuvremenu su održani i izbori 2000. prema nešto izmijenjenim pravilima: uvedene su tzv. otvorene liste, o čemu prethodno nije bilo nikakve javne diskusije i rasprave.

Na krilima ovog uspjeha, žene su vodile aktivnosti uključujući se u rasprave o Izbornom zakonu BIH koji će biti donesen 2001. I pored iznenađujuće jakog otpora uvođenju kvote i u Zakon, što je argumentirano nedemokratskim mehanizmom, ipak je konačno usvojen zakon sa kvotom od 30\% manje zastupljenog spola.

Ono što je dodatno učvrstilo ovu kvotu jeste da je obavezujuća, da su predviđene sankcije za političke subjekte koji je ne poštuju, kao i da je utvrđen redoslijed kandidata i kandidatkinja na listama, posebno do broja osam, a sve definirano u članu 4.19 Izbornog zakona. (Među prva dva obavezno jedno manje zastupljenog spola, među pet-dva i među osam-tri itd.)

Tako su ove datosti svrstale naš Izborni zakon u vrlo povoljan sa stajališta rodne zastupljenosti kao i stvaranja pretpostavki za izbor većeg broja žena $u$ parlamente na različitim nivoima vlasti u BIH. Uvođenje tzv. otvorene liste, a što daje mogućnost biračima da daju svoje preferencije kandidatima i kandidatkinjama, osim da biraju samo stranku, dodatno je demokratiziralo izborni proces, ali i smanjilo početni efekat uvođenja kvote za manje zastupljen spol. Kako u toku rasprava prije usvajanja ovog prvog poslijeratnog Izbornog zakona u BIH nije bilo nikakve diskusije o mogućnosti uspostave sistema otvorene liste, skloni smo vjerovati da ovaj mehanizam i nije došao kao izraz veće demokratije u društvu nego da je prije imao zadaću umanjiti efekat kvote za manje zastupljeni spol. Ovo je samo pretpostavka, bez dokaza, ali će kasniji događaji pokazati ispravnost ove pretpostavke. I u 2005. i 2009. bilo je pokušaja smanjenja kvote i zatvaranja listi, ali su, na sreću, svi ti pokušaji zaustavljeni. Posebno je zanimljiv pokušaj 2009, kada je, tragom preporuka i CEDOW komiteta da se moraju pronaći mehanizmi i stvoriti pretpostavke da u konačnici bude više žena izabranih u zakonodavna tijela, čak i Komisija 
za ravnopravnost spolova Parlamentarne skupštine $\mathrm{BiH}$ i Agencija za ravnopravnost spolova $\mathrm{BiH}$ zagovarali zatvorene liste kao moguću mjeru za veći broj izabranih žena. Istini za volju, tad su rezultati, i pored kvote na listama, bili daleko od zadovoljavajućih, ispod $20 \%$.

Interesantno je da je argumentacija koja je korištena u obrazlaganju za zatvaranje listi bila potreba za izborom većeg broja žena u parlamente. Dakle, briga za ravnopravnost spolova, a što je, zapravo, bio manevar onih politika kojima nije odgovaralo da preferencijalni glasovi narušavaju redoslijed na listama koje su stranke, bolje rečeno njeni lideri, uspostavljali! Treba reći da tad nije vođena nikakva javna diskusija među ženskim niti drugim organizacijama, osim u klubovima političkih stranaka. Jedino je list Oslobođenje otvorio svoje stranice za ovu raspravu, i svi koji su pisali o ovoj problematici usprotivili su se zatvaranju listi obrazlažući stav sužavanjem demokracije i prava biračima da zaista i biraju.

U međuvremenu je došlo do promjene Izbornog zakona 2012/13. tako što je kvota manje zastupljenog spola povećana na 40\% čime je naš Izborni zakon usklađen sa stavovima Evropske unije o ravnopravnosti spolova kao i sa Zakonom o ravnopravnosti spolova.

Kako su liste ostale otvorene i pored nekoliko pokušaja promjene, desne stranke su osmislile i usvojile dodatni mehanizam kako bi smanjile mogućnost remećenja utvrđenog redoslijeda na stranačkoj listi, ako je neko dobio veći broj preferencijalnih glasova od prethodnika na listi. Tako je uspostavljen uvjet da kandidat ili kandidatkinja moraju osvojiti najmanje $20 \%$ glasova svoje liste na općim izborima i $10 \%$ na lokalnim, kako bi se stekli uvjeti za pomjeranje i promjenu mjesta na listi.

Treba naglasiti da se u našem kompliciranom izbornom sistemu samo $70 \%$ mjesta u entitetskim i državnom parlamentu popunjava direktnim izborom, a da $30 \%$ otpada na tzv. kompenzacione mandate koji se, posebnom matematikom, raspodjeljuju između stranaka koje su prešle izborni prag. Formiranje kompenzacionih listi, takođe, podliježe pravilu 4.19, samo što na dodjelu mandata sa ovih lista ,koje prave lideri stranaka, nikakav uticaj nemaju glasači niti broj osvojenih glasova na redovnoj listi. I, obično, kad se razmišlja o mogućnosti povećanja broja izabranih žena, često se spominju baš kompenzacione liste kao eventualni resurs koji bi mogao povećati broj žena bar do broja predviđenog kvotom.

Dakle, i uvođenje kvota, pa potom pokušaj njihovog smanjenja, pokušaji da se liste zatvore, kao i drugi mehanizmi ograničavanja pomjeranja na listi, pokazuju, zapravo, pravo lice naših političkih stranaka i njihovih lidera 
nedovoljno spremnih na dalju demokratizaciju izbornog procesa i stalnu želju da sve procese drže čvrsto u svojim rukama i njima upravljaju. Zapravo, pokazuju i svoj škrti pogled na mogućnost većeg učešća žena u parlamentima i mjestima odlučivanja. Naravno, u prilog ovoj tvrdnji ide i samo letimični pogled na broj izabranih žena u izvršnim i drugim organima vlasti, a za šta ne postoji obavezujuća zakonska kvota. Isto tako mogućnost tzv. dobrovoljne kvote, dakle kvote u političkim strankama, iskoristio je samo mali broj stranaka, što sve govori o suštinskom odnosu prema ženama i pojačava deklarativno izjašnjavanje i potporu pitanjima ravnopravnog učešća žena i ukupne rodne ravnopravnosti.

Brojke su neumoljive i pravi su indikatori stvarnog odnosa:

"Uprkos postojanju pomenutih izbornih kvota, žene su u predstavničkim tijelima na svim nivoima vlasti u Bosni i Hercegovini nedovoljno zastupljene i čine $23,8 \%$, što je ispod evropskog prosjeka. Zastupljenost žena u skupštinama opština/općinskim vijećima u BIH je još i manja i, nakon lokalnih izbora 2016. godine, iznosi svega 18.3\%. Pored toga, od 142 opštine/općine u BiH, samo njih sedam vode načelnice, odnosno - manje od 5\%!'(Agencija za ravnopravnost spolova $\mathrm{BiH}$, pismo pol. strankama, 2020)

"U Bosni i Hercegovini jednaka zastupljenost je jedno od centralnih pitanja ravnopravnosti rodova. Ona je zagarantovana Zakonom o ravnopravnosti spolova i uključuje obavezu na postupanje ako zastupljenost žena i muškaraca padne ispod $40 \%$. Na globalnom planu žene čine nešto više od $50 \%$ populacije, a ipak samo $23,4 \%$ izabranih političkih položaja na svjetskom nivou. Nedovoljna zastupljenost žena na izabranim položajima rezultirala je pozivima na postupanje s ciljem povećanja broja žena u zakonodavnim tijelima koje su uputile međunarodne organizacije, organi iz sporazuma i relevantne organizacije u regionu."(Polazna studija o barijerama političkom učešću žena u BiH, Žene na izborima u BIH, 2020)

Sve ovo govori u prilog potrebe očuvanja kvote za manje zastupljeni spol u narednim reformama Izbornog zakona, kao i očuvanje kaznenih odredbi za one koji to ne poštuju.

Napomenimo da trećina izbornih sistema u svijetu (87) ima zakonsku kvotu za manje zastupljeni spol.

Činjenica je da su kvote uveliko popravile rodnu zastupljenost u našim parlamentima, doprinijele povećanju broja žena, ali je i činjenica da su rezultati i efekti koje daju kvote daleko ispod procenta koji je zagovaran i Pekinškom platformom, a i zacrtan našim zakonima. 
Godinama se ovo konstatira i ponavlja iz izvještaja u izvještaj, iz konferencije u konferenciju, a da pri tom nema konkretnih prijedloga šta činiti kako bi se ispunila očekivanja stvorena zacrtanom kvotom.

Naravno, uzroci su različiti i malobrojna istraživanja će ustvrditi da su isprepleteni i da nikako nema onih za koje se može reći da su presudni.

"Mnoge organizacije smatraju Izborni zakon BiH ključnom preprekom za učešće žena u politici iako su nalazi ove studije u suprotnosti s njihovim izjavama. Postoji samo jedan prijedlog za izmjenu. Mnogi omogućitelji svoje aktivnosti usmjeravaju na aktivnosti žena u politici i smatraju političke stranke vratarima za učešće žena."( Polazna studija o barijerama političkom učešću žena u BiH,Žene na izborima u BIH, 2020)

Ne treba zanemariti ni činjenicu “da u BiH postoje rodni stereotipi o ženama i muškarcima u politici što ima negativan uticaj na rodnu ravnopravnost. Većina medija prenosi dominantne rodne stereotipe o ženama na izborima i žene dobijaju manje prostora nego muškarci”( Kritička analiza nivoa suštinske zastupljenosti žena postignutog kvotama, A. Kadribašić)

Kad se govori o pogodnostima izbornog sistema za veće učešće žena, onda se apostrofira proporcionalni sistem, kvote i obavezujući raspored na listama. Problematizirane su otvorene liste, veliki broj političkih stranaka koje sudjeluju na izborima, broj izbornih jedinica i mogućnost ograničenog broja izabranih u tim izbornim jedinicama i sl. U malom broju istraživanja su sve ove varijable podvrgnute provjeri i izračunu sa stajališta uticaja na rodnu ravnopravnost i mogućnost izbora većeg broja žena u zakonodavna tijela. Najkonkretnije i najozbiljnije istraživanje napravio je Sarajevski otvoreni centar (SOC, Kako do 40\% žena u zakonodavnim tijelima BIH? Analiza mogućih intervencija u izbornom sistemu $\mathrm{BiH}, 2015)$ koji je ponudio i sasvim konkretne prijedloge za izmjene i dopune Izbornog zakona, a koje djeluju razložno i prihvatljivo i što je najvažnije, usvajanje njihovih prijedloga bi obezbijedilo zadovoljavanje kvote od $40 \%$ izabranih. Tako bi bila postignuta konkretizacija obaveza koje su BIH i njeni politički akteri preuzeli na putu ka EU.

Objektivno, nema puno prostora u zakonu za poboljšanje efekata kvote. Prostor za poboljšanje treba tražiti, prije svega, u ukupnoj demokratizaciji društva i posebno u poboljšanju demokratskog ozračja u političkim strankama. Tamo je još uvijek politika u muškim rukama, kao, uglavnom, i sve bitne pozicije. Vrlo sporo se mijenja taj odnos i u programskim dokumentima i statutima, a još sporije u njihovoj primjeni. U tom smislu je, možda, najdalje otišao SDP BIH koji je programski zacrtao paritet, statutarno poštivanje 
zakonske kvote, a i napravio iskorak za lokalne izbore 2020. i u Pravilnik za izbore unio obavezujuću kvotu na listama 50:50, uz ravnomjeran raspored kandidata muškog i ženskog spola. Naravno, potrebno je voditi intenzivne aktivnosti kako bi ova „dobrovoljna“" kvota potpuno zaživjela.

I upravo je, eventualno, povećanje kvote na $50 \%$ bila jedna od varijanti koju je SOC testirao kao mogućnost, a koja bi obezbijedila 40\% izabranih. Test je pokazao da ni povećanje tog procenta ne bi dovelo do bitnog povećanja izabranih na entitetskom i državnom nivou zbog dizajna izbornih jedinica, ali i broja stranaka koje učestvuju na izborima(u BIH ih ima oko 150), osim, vjerovatno, na lokalnom nivou gdje u pravilu stranke osvajaju veći broj mjesta, što povećava i mogućnost da bude izabran i veći broj žena. (SOC, Kako do izabranih $40 \%, 2015)$

No i pored ove konstatacije, zdušno se zalažu za povećanje kvote na 50\%, jer bi to psihološki djelovalo na birače i samim tim uticalo da malo odstupe od svojih navika da preferiraju muškarce.

Sličan efekat su dobili i propitujući eventualno povećanje izabranih žena kod zatvaranja liste. Istina, zatvorene liste bi nešto povećale procent izabranih koji bi i dalje bio ispod željenih $40 \%$, a pri tom bi bila biračima oduzeta mogućnost da slobodno biraju imenom i prezimenom sa liste stranke za koju su se opredijelili, te bi time bila žrtvovana već stvorena dobra demokratska praksa.

Ono što posebno zavređuje pažnju u pomenutoj analizi SOCa je variranje sa modelom koji se vrlo uspješno primjenjuje na Kosovu, tzv Lucky Looser, sretni gubitnik.

Prema tom modelu, nakon izbora, lista izabranih žena se puni do $30 \%$ tako što svaka sljedeća sa liste preskače muškarca ispred sebe sve dok se ne popuni kvota od 30\% žena. Ovim sistemom se obezbjeđuje zadata kvota izabranih, ali se ujedno atakuje na izbornu volju birača, što u našim uvjetima nikako ne bi moglo biti prihvaćeno niti bi politički subjekti u BiH ikad prihvatili ovakvo rješenje.

Zato SOC u svojoj analizi predlaže nešto modificiran ovaj model Lucky Looser, na način da se sa kompenzacione liste popunjava nedostajući broj izabranih žena do $40 \%$. Tako se ne bi diralo u izbornu volju birača, a ovakva bi izmjena izbornih pravila, vjerovatno, lakše prošla kod političkih stranaka koje odlučuju u Parlamentu.

Svakako bi u jeku rasprava o izmjenama Izbornog zakona trebalo uzeti u obzir i ove prijedloge. 
Naravno, ovo podrazumijeva istinsku opredijeljenost za stvaranje zakonskih pretpostavki za veće učešće i posebno veći izbor žena u parlamente.

Dakle, ako bismo zaključivali , onda bismo rekli sljedeće:

Potrebno je ostati kod proporcionalnog izbornog sistema sa mogućnošću preferencijalnog glasanja, što znači i zadržavanje otvorenih listi.

Potom, veoma je važno zadržati kvotu manje zastupljenog spola i povećati je na 50\%, dakle založiti se za paritet i ravnomjeran raspored muškaraca i žena na listi.

Svakako je potrebno zadržati i kaznene odredbe za nepoštivanje obaveznih kvota.

Kako bi se obezbijedilo 40\% izabranih žena, primijeniti modificirani model tzv.Lucky Looser, onako kako to predlaže SOC.

Također, potrebno je stvarati atmosferu da se smanji broj političkih subjekata koji učestvuju na izborima, djelimično i podizanjem cenzusa za ulazak u zakonodavna tijela.

I pored svih ovih mogućnosti za zakonska poboljšanja kako bi broj izabranih žena bio zadovoljavajući i u skladu sa proklamovanim politikama, još značajniju ulogu mogu i trebalo bi da odigraju političke stranke stvarajući demokratsko ozračje u svojim redovima, a što bi bitno uticalo i na stvaranje ukupne pozitivne atmosfere u društvu za ravnopravno opredjeljivanje za izbor i muškaraca i žena, a bez nepovjerenja i bez stereotipa.

\section{Increase in the Women's Participation and $\mathrm{BiH}$ Election Law}

\section{Summary}

The period from 1995 until today has been, among other, marked with search for potential models that could secure higher level of women participation not only in legislative bodies but in the executive government and in social and political life in general as well. This is a process that is been continuously conducted in large part of the world, including our $\mathrm{BiH}$ and the region. Persistent lack of women at the decision-making positions is most often assigned to our traditional cultural and general social conditions, insufficient democratization of political parties, as well as to the lack of appropriate legislative solutions that would enable good conditions for higher number of women on the lists and in the government bodies. The adoption of the BiH Law on Gender Equality, introduction of quota for less represented sex into 
the Election Law, in addition to other solutions, has greatly impacted the increase of women in legislative positions. However, this number is still far less than the proclaimed $30 \%$ at first, and subsequently $40 \%$ obligatory quota of less represented sex on the candidacy lists. There are very few researchers that offer potential concrete amendments to the law that would help in reaching this percentage. It is a general opinion that current election system in $\mathrm{BiH}$ favors higher representation of women as less represented sex. It, however, also opens some possibilities for improvement that are hidden in potential parity and equal representation of women and men on the lists, potential closing of the lists, redistribution of the compensatory mandates in favor of the less represented gender, and similar. Also, it would be useful to reconsider the number of political parties, number of election units, as well as raising the census for mandates. In addition, it would be important to preserve the quota which has been attacked so many times in the past 20 years, and keep the provisions that protect prescribed sequence and the quota. The amendments that would favor increase in the number of elected women seek appropriate political climate. That is why it is important to assign the responsibility not only to the legislative decision-makers but especially to the political parties, media, NGO, and other stakeholders.

Key words: equality, equal representation, gender quota, open and closed lists, changes to the compensatory lists, preservation of positive solutions, responsibility of political parties 